\title{
Ephedra alata fruit extracts: phytochemical screening, anti-proliferative activity and inhibition of DPPH, a-amylase, a-glucosidase, and lipase enzymes
}

\author{
Nidal Jaradat*, Hanaa Dacca, Mohammed Hawash and Murad N. Abualhasan
}

\begin{abstract}
Background: Discovering and screening for potential anti-obesity, anti-diabetic, anticancer, and antioxidant treatments from natural products still in recent times the main goal for many pharmaceutical scientists. The present investigation aimed to evaluate the chemical constituents of Ephedra alata fruits various extracts and to assess their antioxidant, antiobesity, antidiabetic, and cytotoxic effects.

Result: In this work, high content of flavonoids and phenols were observed in the methanol fraction of $E$. alata fruits, which reached $98.95 \mathrm{mg}$ of RUE/g and $33.22 \mathrm{mg}$ of GAE/g, respectively. The methanol fraction has significant inhibitory activity against DPPH, a-amylase, a-glucosidase, and lipase with an IC ${ }_{50}$ value of 1.07, 9.43, 46.16, and $66.48 \mu \mathrm{g} /$ $\mathrm{mL}$. respectively. Also has anticancer activity against HeLa cancer cell line. While the acetone fraction has potent antioxidant activity with $\mathrm{IC}_{50} 5 \mu \mathrm{g} / \mathrm{mL}$.

Conclusion: The DPPH and digestive enzymes assays results showed that the methanolic fraction of E. alata fruits has potent antioxidant, anti-diabetic, and anti-obesity activities, which can be an excellent candidate for biological and chemical analysis and can be further subjected for isolation of the therapeutically active compounds with anticancer potency.
\end{abstract}

Keywords: Phytochemical, Ephedra alata, DPPH, a-Amylase, a-Glucosidase, Lipase, Cytotoxicity

\section{Introduction}

Most of the population still depends on natural remedies, especially in developing countries. In the past, ancient civilizations depended on local flora and fauna for their survival needs. Despite the fact that some preparations possibly caused harmful effects, or worked by a ceremonial or placebo effect, traditional healing formulations usually had a substantial active pharmacopeia [1]. Ephedra alata Decne. (E. alata), also known as Alanda

*Correspondence: nidaljaradat@najah.edu Department of Pharmacy, Faculty of Medicine and Health Sciences, AnNajah National University, P.O. Box 7, 00970 Nablus, State of Palestine in Arabic, is a member of the Ephedraceae family. This subspecies is a perennial genus that can exceed more than one meter in height, has a strong pine odor and an astringent taste, belongs to the Gnetales plant, and is the closest living relative of the angiosperm. This ephedra subspecies is native to Iran, Algeria, Egypt, Palestine, Lebanon, Jordan, Iraq, Saudi Arabia, Morocco, Libya, and Tunisia [2,3]. This plant has a light green, densely branched dioecious, small and perennial stiff shrub, about $50-100 \mathrm{~cm}$ tall, the twigs appear leafless and the leaves are reduced to small scales, the cones are sessile shaped and clustered in the axils or at branch tips (Fig. 1) [4]. Ephedra alata was globally used in folk medicine, 


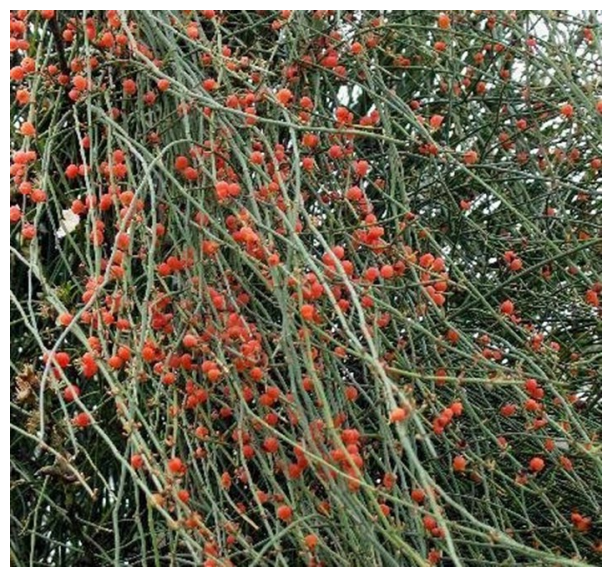

Fig. 1 Ephedra alata plant red fruits

especially its stems, as a decoction of these stems were used as a stimulant, treatment for kidney health problems, bronchial asthma, circular system disorders, and digestive system disturbances, as well as for treatment of cancer. Also, the plant stems are chewed to treat bacterial and fungal infections-especially in oral bacterial and fungal infections $[5,6]$.

The decongestant effect of $E$. alata stems resulted in its widespread use in medicine for the treatment of cough and sinusitis. In Palestine, E. alata has been used in folk medicine to treat the common cold, hay fever, asthma, and in the last few years, it was extensively used for the treatment of cancer [7]. Furthermore, the different extracts of E. alata were used as depurative, hypotensive, astringent, and anti-asthmatic natural products. The branches of E. alata also seemed to be masticated for cephalalgia, used in miscarriage, and as a bronchodilator, antifungal, and antimicrobial natural agents [8].

The pharmacological effect of the different Ephedra species depends on the phytoconstituents of each one. As shown in general studies, the Ephedra species were characterized by the alkaloids and phenolic compounds content, such as trans-cinnamic acid, catechin, epicatechin, symplocoside, and flavonol-3-O-glycosides, and proanthocyanidins [9].

Oxidation is a process that occurs within the human body that causes damage to cell membranes and other structures, including cellular proteins, lipids, and DNA molecules. When oxygen is rapidly metabolized, it will produce unstable molecules called free radicals that usually steal electrons from other molecules, resulting in DNA damage and other body cells. However, the damage caused by an excessive upload of free radicals over time may become irreversible and lead to certain dangerous diseases, including heart disease, liver disease, and some types of cancers, especially oral, stomach, esophageal, and bowel cancer [10].

According to data collected from the World Health Organization (WHO) global survey on traditional, complementary/alternative, and herbal medicines, the market for these kinds of medicines is steadily growing worldwide. In actuality, the utilization of phytopharmaceuticals and nutraceutical productś is continuously expanding. Nowadays, many people have been using these natural formulations in the treatment or prevention of various diseases and health disorders in different national healthcare centers $[11,12]$.

The worldwide incidence of diabetes is increasing every year. Based on information from the International Diabetes Federation the estimated number of people with diabetes reached 30 million in 1985, 150 million in 2000, and 246 million in 2007. They also expect that the number of diabetic patients may hit 380 million by 2025 [13]. This health problem prevails worldwide with its occurrence rising at an alarming rate all over the world. Different complications encompass all the vital organs of the human body as a consequence of the metabolic derangement in diabetes $[14,15]$.

Cancer is a condition that refers to different types of diseases that are typically characterized by rapid and abnormal growth of human cells beyond the usual boundaries - proliferation cannot be controlled and cells acquire anti-apoptosis features giving them the ability to penetrate and destroy the normal body tissue. Also, cancer can spread and affect any organ or part of the human body [16]. The development process for cancer drugs has relied on natural products where more than $70 \%$ of the available anti-cancer drugs are from natural resources, and plants are most often used. However, more than 3000 plants in the world have been reported and known to have anti-cancer properties [17].

The objective of the present study is to investigate the chemical composition of E. alata various extract and to correlate the chemical profile with the antioxidant activity, pancreatic lipase inhibitory, carbohydrate-hydrolyzing enzymes, and anticancer properties.

\section{Materials and methods}

\section{Chemicals and reagents}

The following materials were purchased from Frutarom (Israel), Sigma-Aldrich (Germany, USA, and Denmark), Riedel-de Haen (Germany), Alfa-Aesar (England) and Loba/Chemie, Merck, SDFCL (India): Ferric chloride, sulfuric acid $\left(\mathrm{H}_{2} \mathrm{SO}_{4}\right)$, methanol, iodine, Benedict's solution, hexane, acetone, chloroform, Molisch's reagent, Trolox ((s)-(-)-6 hydroxy-2,5,7,8-tetramethychroman2-carboxylic acid, Acarbose, $\alpha$-glucosidase (Baker's Yeast 
alpha-glucosidase), $\alpha$-amylase, 3,5-dinitrosalicylic acid (DNSA), potassium phosphate, Gallic acid, sodium carbonate, sodium hydroxide $(\mathrm{NaOH})$, hydrochloric acid $(\mathrm{HCl})$, Ninhydrin reagent, magnesium ribbon, FolinCiocalteu's reagent, L-glutamine solution, MTS reagent, phosphate-buffered saline, a Pen-Strep solution composed of penicillin and streptomycin, 2,2-Diphenyl1-picrylhydrazyl (DPPH), porcine pancreatic amylase enzyme solution, and starch.

\section{Samples and extraction procedures}

The E. alata fruits were collected from the Jenin area of Palestinian sites in July of 2018. Identifications were performed by the pharmacognosist Dr. Nidal Jaradat, at the Pharmacognosy Laboratory at An-Najah National University-Nablus Palestine (voucher series: PharmPCT-904). The fruits were washed and cleaned two times with distilled water and dried in the oven at 40 ${ }^{\circ} \mathrm{C}$. Finally, the fruits were grounded into powder by the mechanical grinder and kept in a well-closed container with a suitable label for further use.

The extraction process adopted in this research was based on the fractional extraction procedure, which conducted by adding different solvents sequentially based on their polarity, starting with the most nonpolar solvent, hexane, followed by acetone (polar aprotic organic solvent), then methanol-a highly polar, low molecular weight alcohol-and finishing the extraction steps with distilled water (polar inorganic solvent). For the preparation of each extract fraction, $25 \mathrm{~g}$ of the dried, grounded fruits were first soaked in $0.5 \mathrm{~L}$ of hexane for $72 \mathrm{~h}$ (three days) in a shaker device, with continuous shaking at approximately 100 rounds/minute at room temperature. Then, the hexane was replaced with $0.5 \mathrm{~L}$ of acetone at the same conditions mentioned above, followed by methanol and finally distilled water. Each organic fraction was filtered using suction filtration and concentrated under a vacuum on a rotary evaporator, while the aqueous fraction was collected as a powder using a freeze dryer. All crude fractions were kept at $4{ }^{\circ} \mathrm{C}$ for further use [18].

The yield of each extract fraction was calculated using the following formula:

$$
\begin{aligned}
\% \text { Yield }= & (\text { Weight of } E . \text { alatafruits extract } \\
& / \text { weight of dry fruits }) \times 100 \%
\end{aligned}
$$

\section{Determination of total phenol content (TPC)}

The content of total phenolic compounds of E. alata fruits for four different extracts was assessed using the
Folin-Ciocalteu's reagent (FCR). FCR, or Folin's phenol reagent, is a mixture of phosphomolybdate and phosphotungstate used for the colorimetric assay of phenolic and polyphenolic antioxidants.

Using a $100 \mathrm{~mL}$ volumetric flask, a $7.5 \%$ sodium carbonate $\left(\mathrm{Na}_{2} \mathrm{CO}_{3}\right)$ solution was prepared by dissolving $7.5 \mathrm{~g}$ of $\mathrm{Na}_{2} \mathrm{CO}_{3}$ in less than $100 \mathrm{~mL}$ of distilled water, then, distilled water was used to bring the volume up to $100 \mathrm{~mL}$. Similarly, to sodium carbonate solution, a stock solution of the standard solution (Gallic acid solution) was prepared by dissolving $100 \mathrm{mg}$ of gallic acid and dissolved up to $100 \mathrm{~mL}$ of distilled water. The reaction mixture was prepared by mixing $0.5 \mathrm{~mL}$ of each extract solution, $2.5 \mathrm{~mL}$ of $10 \%$ Folin-Ciocalteu's reagent dissolved in water, and $2.5 \mathrm{~mL}$ of $7.5 \%$ sodium carbonate $\left(\mathrm{Na}_{2} \mathrm{CO}_{3}\right)$ in a test tube for each sample. The sample tubes were incubated for $45 \mathrm{~min}$ at $45{ }^{\circ} \mathrm{C}$. The absorbance was determined using a spectrophotometer at wavelength $765 \mathrm{~nm}$. The samples were prepared in triplicate for each analytic trial to obtain the mean and standard deviation values [19].

\section{Determination of total flavonoid content (TFC)}

Total flavonoid content (TFC) was determined according to the procedure adopted by Chang et al. The TFC was calculated from the calibration curve of Rutin (the used standard) and expressed as the milligram of Rutin Equivalent per gram of extract (mg RUE/g extract).

The calibration curve for Rutin was established using serial dilutions, starting with the preparation of a stock solution of $100 \mu \mathrm{g} / \mathrm{mL}-10 \mathrm{mg}$ of Rutin was dissolved in $10 \mathrm{~mL}$ of distilled water and diluted to $100 \mathrm{~mL}$. Subsequently, the stock solution was diluted to provide a series of concentrations of $10,30,40,50,70$, and $100 \mu \mathrm{g} / \mathrm{mL}$.

For the preparation of the working solutions, $0.5 \mathrm{~mL}$ of each solution was mixed with $3 \mathrm{~mL}$ methanol, $0.2 \mathrm{~mL}$ of $10 \% \mathrm{AlCl}_{3}, 0.2 \mathrm{~mL}$ of $1 \mathrm{M}$ potassium acetate, and $5 \mathrm{~mL}$ of distilled water, and then, incubated at room temperature for $30 \mathrm{~min}$. The previous steps were performed for each fruit extract fraction, and finally, the absorbance was recorded at a $415 \mathrm{~nm}$ wavelength, and distilled water with methanol, $10 \% \mathrm{AlCl}_{3}$, and potassium acetate was used as a blank solution. The samples were prepared in triplicate for each analytic trial to obtain the mean and standard deviation values [20].

\section{Determination of total tannin content (TTC)}

For total tannin content assessment, according to the method of Sun et al., the four E. alata fruit extract 
Table 1 Phytochemical screening tests for different extract fractions of E. alata fruits

\begin{tabular}{|c|c|c|c|c|}
\hline Phytochemical active constituent & Hexane extract & Acetone extract & Methanol extract & $\begin{array}{l}\text { Aqueous } \\
\text { extract }\end{array}$ \\
\hline $\begin{array}{l}\text { Protein \& amino acids } \\
\text { Biuret test }\end{array}$ & - & - & + & + \\
\hline $\begin{array}{l}\text { Reducing sugars } \\
\text { Fehling's test }\end{array}$ & - & - & - & + \\
\hline $\begin{array}{l}\text { Complex polysaccharides } \\
\text { Molisch's test }\end{array}$ & + & + & - & - \\
\hline $\begin{array}{l}\text { Starch } \\
\text { lodine test }\end{array}$ & - & - & - & + \\
\hline $\begin{array}{l}\text { Phenols } \\
\text { Ferric chloride test }\end{array}$ & + & + & + & + \\
\hline $\begin{array}{l}\text { Tannins } \\
\text { Gelatin test }\end{array}$ & + & + & + & + \\
\hline $\begin{array}{l}\text { Flavonoids } \\
\text { Shinoda reagent }\end{array}$ & - & + & + & + \\
\hline $\begin{array}{l}\text { Saponin } \\
\text { Foam test }\end{array}$ & - & - & - & + \\
\hline $\begin{array}{l}\text { Glycosides } \\
\text { Keller-Killani Test }\end{array}$ & - & - & - & - \\
\hline Steroids & + & - & - & - \\
\hline $\begin{array}{l}\text { Terpenoids } \\
\text { Salkowski's test }\end{array}$ & + & - & - & - \\
\hline $\begin{array}{l}\text { Alkaloids } \\
\text { Wagner's test }\end{array}$ & + & + & + & + \\
\hline $\begin{array}{l}\text { Volatile oil } \\
\mathrm{KOH} \text { test }\end{array}$ & - & - & + & - \\
\hline
\end{tabular}

Where (+) means the presence of phytochemicals and (-) absence of phytochemicals

Table 2 The yield percentage for four extract fractions of E. alata fruits

\begin{tabular}{lll}
\hline Extract Fractions & Extract $\mathbf{( g )}$ & Yields (\%) \\
\hline Hexane & $2.15 \mathrm{~g}$ & $8.6 \%$ \\
Acetone & $3.9 \mathrm{~g}$ & $15.6 \%$ \\
Methanol & $7.25 \mathrm{~g}$ & $29 \%$ \\
Aqueous & $3.77 \mathrm{~g}$ & $15.08 \%$ \\
\hline
\end{tabular}

Table 3 Absorbance values of the STDs at different concentrations

\begin{tabular}{llllll}
\hline Conc. of STDs and $\lambda$ max & & & & & \\
\hline Conc. of Gallic acid $(\mu \mathrm{g} / \mathrm{mL})$ & 0 & 10 & 40 & 50 & 70 \\
Abs. at $\lambda \max =765 \mathrm{~nm}$ & 0 & 0.142 & 0.496 & 0.557 & 0.798 \\
Conc. of Rutin $(\mu \mathrm{g} / \mathrm{mL})$ & 0 & 10 & 30 & 50 & 60 \\
Abs. at $\lambda \max =415 \mathrm{~nm}$ & 0 & 0.049 & 0.11 & 0.17 & 0.2 \\
Conc. of Catechin $(\mu \mathrm{g} / \mathrm{mL})$ & 0 & 10 & 30 & 50 & 70 \\
Abs. at $\lambda_{\max }=500 \mathrm{~nm}$ & 0 & 0.028 & 0.041 & 0.056 & 0.077 \\
\hline
\end{tabular}

fractions. Catechin was used as a reference compound to construct the calibration curve for the needed calculations. A $100 \mu \mathrm{g} / \mathrm{mL}$ stock methanolic solution was prepared, and then, serial dilutions were obtained $(10,30$, 50,70 , and $100 \mu \mathrm{g} / \mathrm{mL}$ ).

A $4 \%$ methanolic vanillin solution was prepared freshly. $100 \mu \mathrm{g} / \mathrm{mL}$ stock solution from each fruit extract fraction was prepared using methanol as a solvent. For the working solution, each test tube contained $0.5 \mathrm{~mL}$ from each extract mixed with $3 \mathrm{~mL}$ of vanillin solution and $1.5 \mathrm{~mL}$ of concentrated $\mathrm{HCl}$. The mixture was allowed to stand for $15 \mathrm{~min}$, and then the absorption was measured at $500 \mathrm{~nm}$ against methanolic vanillin as a blank. All working samples were analyzed in triplicate. The total tannin in each fraction was expressed as catechin equivalents (mg of CAE/g of plant fraction) [21].

\section{DPPH radical scavenging activity assay}

The E. alata fruit extract stock solutions were serially diluted to achieve concentrations of 100, 50 20, 10, 5, and $2 \mu \mathrm{g} / \mathrm{mL}$ using methanol as solvent. Each test tube contained $1 \mathrm{~mL}$ of each concentration and was marked 
Table 4 Quantitation of phenols, tannins, and flavonoids in hexane, acetone, methanol, and aqueous fractions of E. alata fruits

\begin{tabular}{llcc}
\hline $\begin{array}{l}\text { E. alata fruit extract } \\
\text { fractions }\end{array}$ & $\begin{array}{l}\text { Total flavonoids contents, } \mathbf{m g} \text { of RUE/g } \\
\text { of dry extract } \pm \text { SD }\end{array}$ & $\begin{array}{l}\text { Total phenol contents, } \mathbf{~ m g ~ o f ~ G A E / g ~ o f ~} \\
\text { dry extract } \pm \text { SD }\end{array}$ & $\begin{array}{l}\text { Total tannin contents, mg of } \\
\text { CAE/g of dry extract } \pm \text { SD }\end{array}$ \\
\hline Hexane & - & $5.72 \pm 0.39$ & $2.5 \pm 0.70$ \\
Acetone & $58.95 \pm 2.33$ & $19.85 \pm 1.62$ & $10.5 \pm 0.70$ \\
Methanol & $98.95 \pm 2.3$ & $33.22 \pm 1.56$ & $17.5 \pm 0.70$ \\
Aqueous & $32.3 \pm 2.4$ & $25.9 \pm 0.78$ & $1.5 \pm 0.70$ \\
\hline
\end{tabular}

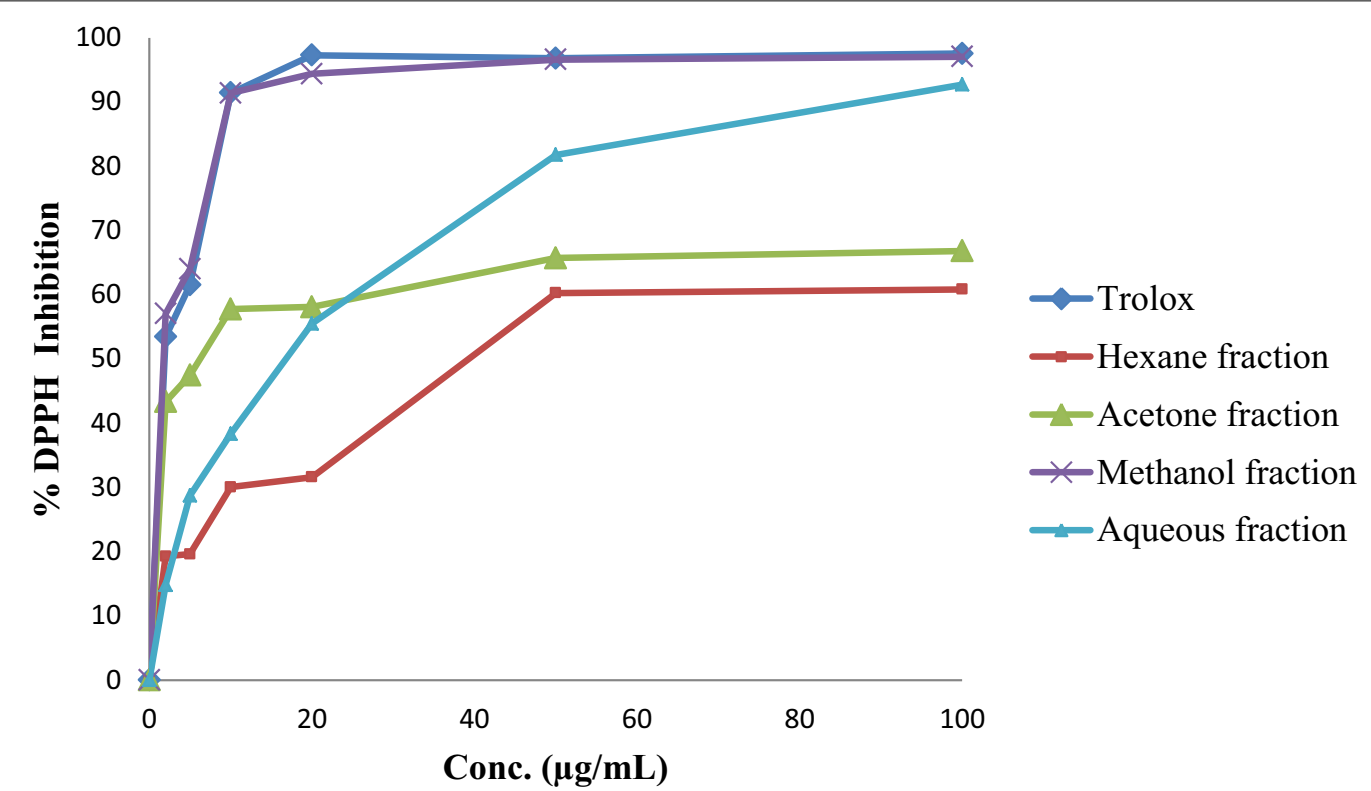

Fig. 2 The DPPH inhibition percentage of the different E. alata fruit extract fractions compared to Trolox (positive control)

Table 5 The $\mathrm{IC}_{50}$ for different extracts fractions against DPPH, Lipase, a-Amylase, and a-glucosidase in comparison of IC ${ }_{50}$ of positive controls

\begin{tabular}{llccccc}
\hline & Target enzymes & Reference & Hexane fraction & Acetone fraction & Methanol fraction & Aqueous fraction \\
\hline $\mathrm{IC}_{50}(\mu \mathrm{g} / \mathrm{mL})$ & $\mathrm{DPPH}$ & $2.04 \pm 0.74^{\mathrm{a}}$ & $44.05 \pm 0.39$ & $5.00 \pm 0.51$ & $1.70 \pm 0.25$ & $15.25 \pm 0.30$ \\
& Lipase & $12.3 \pm 0.33^{\mathrm{b}}$ & $277.25 \pm 0.79$ & $77.56 \pm 0.34$ & $66.48 \pm 0.50$ & $274.407 \pm 0.49$ \\
& a-Amylase & $28.84 \pm 1.22^{\mathrm{c}}$ & $55.01 \pm 1.23$ & $189.94 \pm 2.32$ & $9.43 \pm 0.6$ & $16.37 \pm 0.58$ \\
& a-Glucosidase & $37.15 \pm 0.33^{\mathrm{C}}$ & $167.68 \pm 0.38$ & $\mathrm{NI}$ & $46.16 \pm 0.63$ & $201.77 \pm 0.48$ \\
\hline
\end{tabular}

${ }^{a}$ Trolox, ${ }^{b}$ Orlistat, ${ }^{c}$ Acarbose, Nl: no inhibition (inhibition at concentration higher than $400 \mu \mathrm{g} / \mathrm{mL}$ )

properly. One $\mathrm{mL}$ of $0.002 \%$ methanolic DPPH solution was added to each test tube, and $1 \mathrm{~mL}$ of methanol was added to each test tube to bring the final volume up to $3 \mathrm{~mL}$ (caution: DPPH is light sensitive, so preparation of working test tubes should be performed with minimum light exposure).

The samples were incubated for $30 \mathrm{~min}$ in a dark place, then, their optical densities were determined using the spectrophotometric measurement at a wavelength of $517 \mathrm{~nm}$. The equation used in this analytical study to calculate the inhibition percentage is shown below:

$$
\% \text { DPPH inhibition }=\left(A_{B}-A_{E}\right) / A_{B} \times 100 \%
$$

$A_{B}$ is the recorded absorbance of the blank solution; $A_{E}$ is the recorded absorbance of the $E$. alata sample solution [22]. 


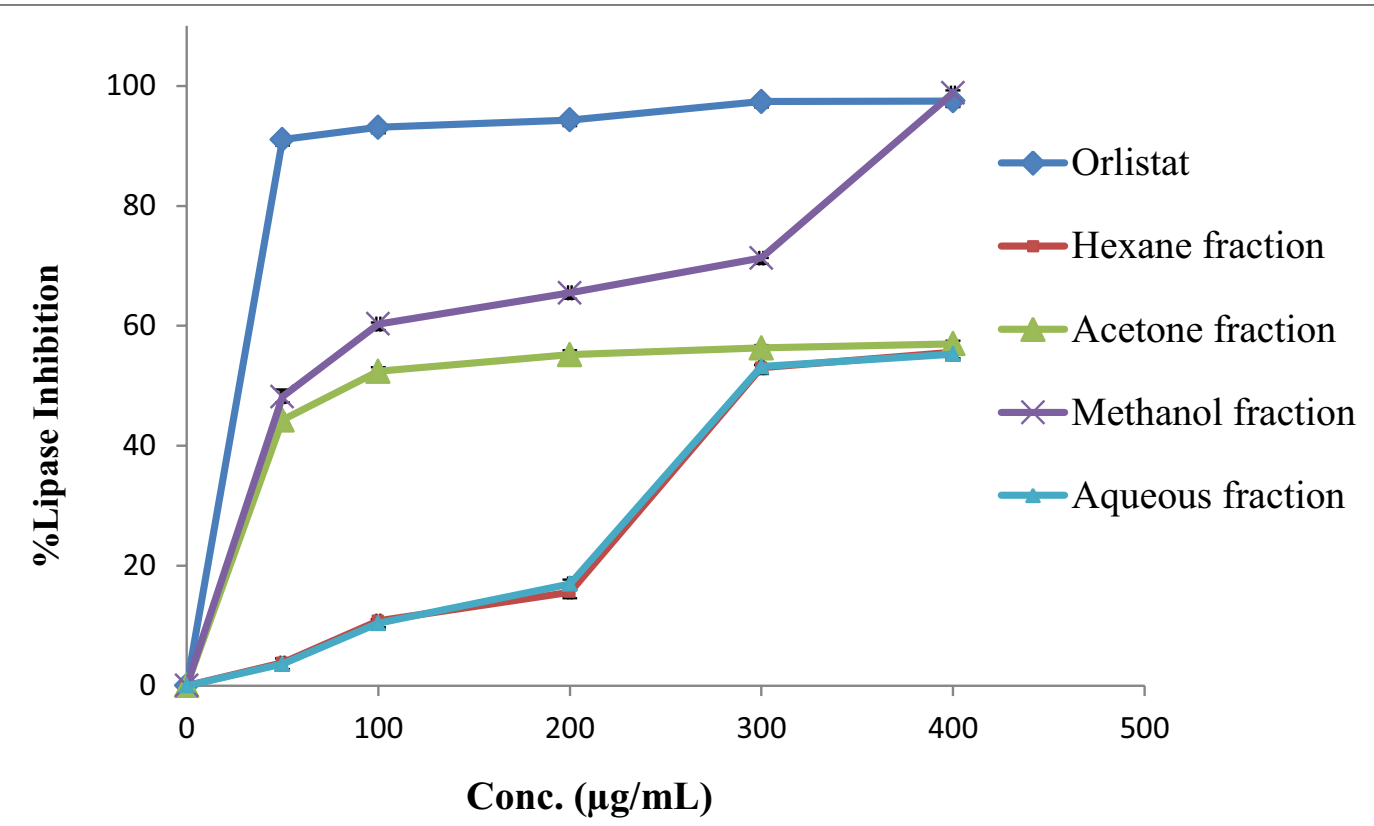

Fig. 3 The lipase inhibition percentage of the different E. alata fruit extract fractions compared to Orlistat (positive control)

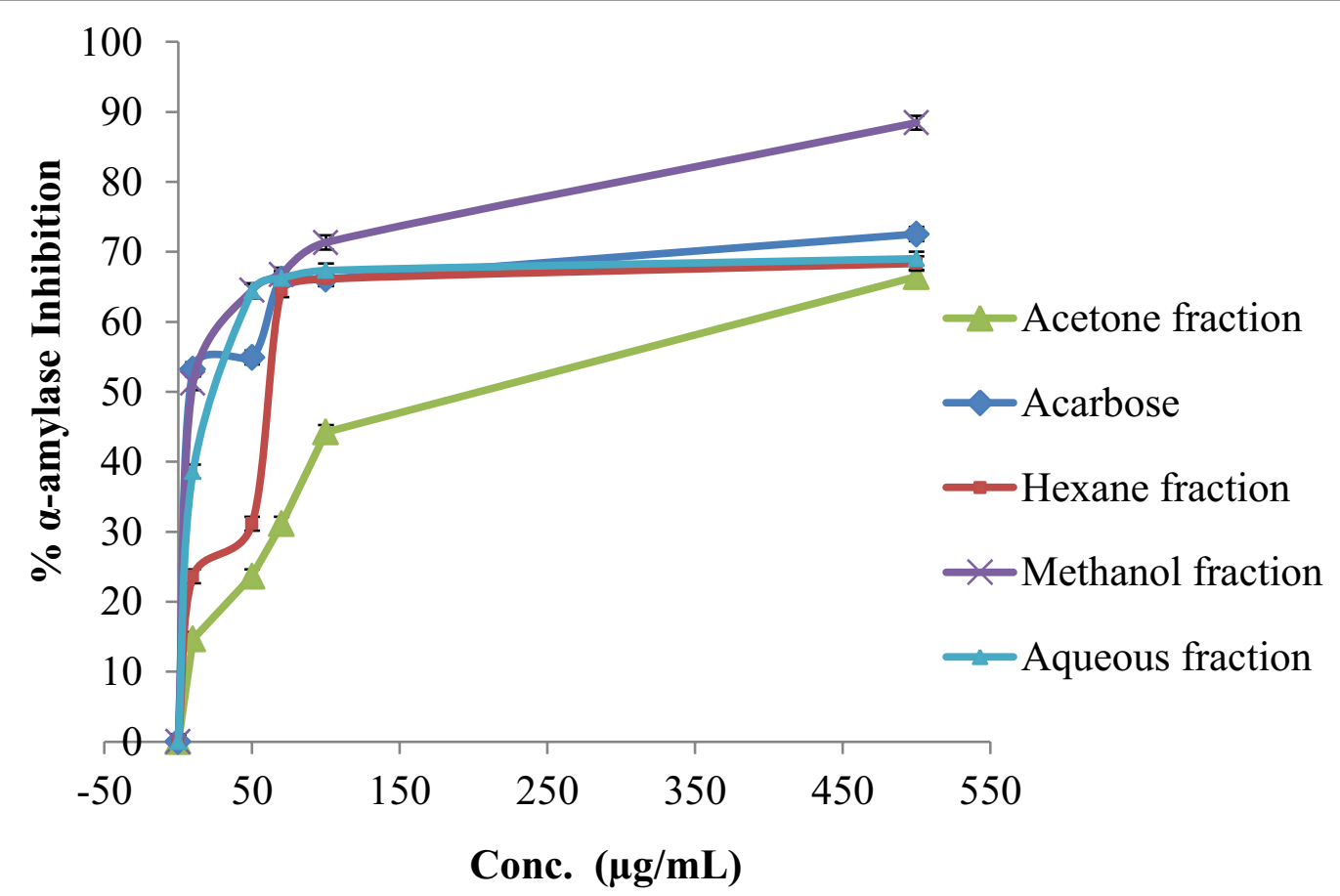

Fig. 4 a-Amylase inhibition percentage of the different E. alata fruit extract fractions compared to Acarbose (positive control)

\section{Porcine pancreatic lipase inhibition assay}

The porcine pancreatic lipase inhibitory method was followed in this study according to protocols from Zheng et al. and Bustanji et al., with some modifications [23]. A stock solution of $500 \mu \mathrm{g} / \mathrm{mL}$ from each plant fraction, in $10 \%$ DMSO, was used to prepare five different solutions with the following concentrations: 50, 100, 200, 300, and $400 \mu \mathrm{g} / \mathrm{mL}$. A $1 \mathrm{mg} / \mathrm{mL}$ stock solution of porcine pancreatic lipase enzyme was freshly prepared in Tris$\mathrm{HCl}$ buffer before use. The substrate used for this study, 


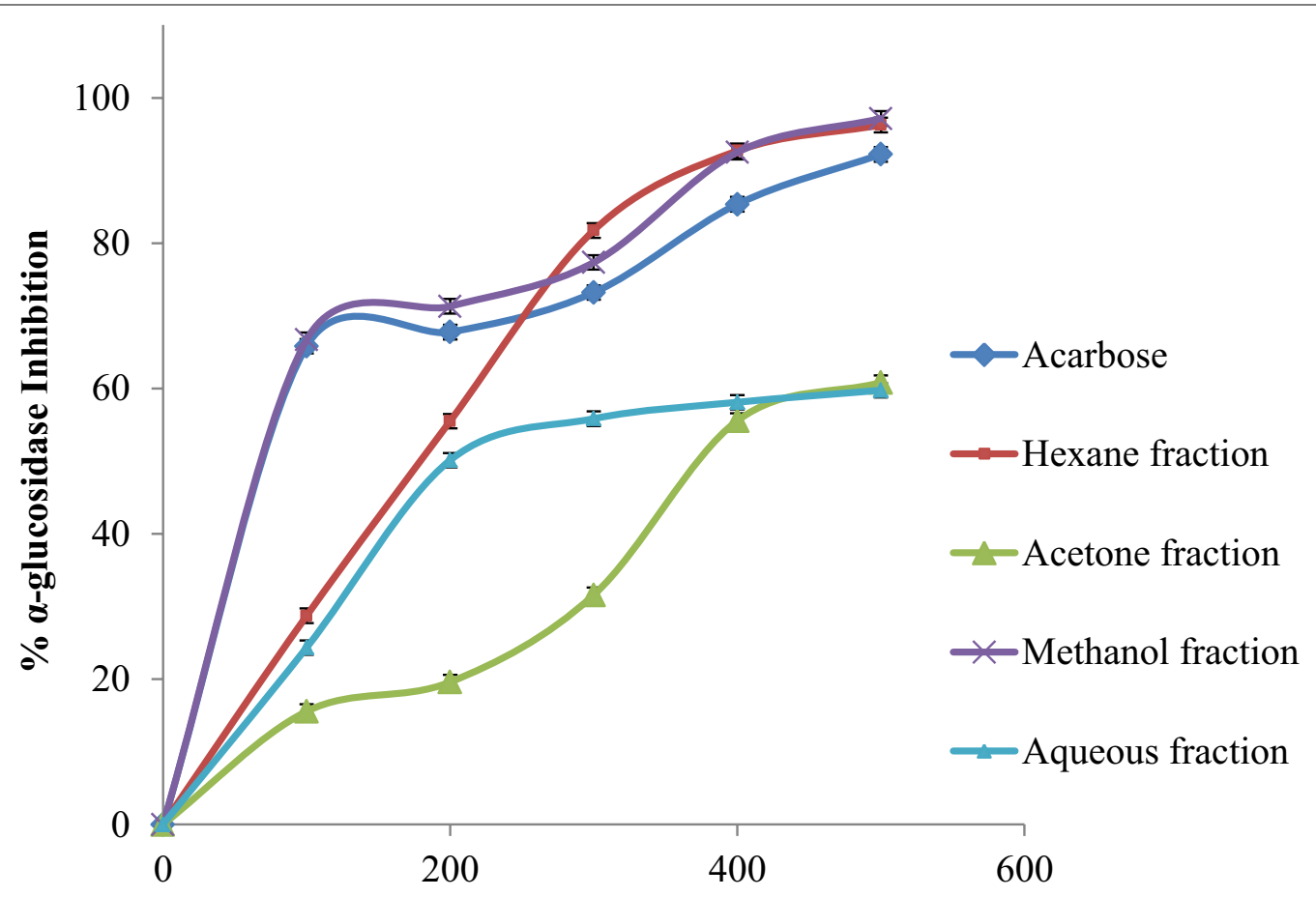

Conc. $(\mu \mathrm{g} / \mathrm{mL})$

Fig. 5 a-Glucosidase inhibition percentage of the different E. alata fruit extract fractions compared to Acarbose (positive control)

p-nitrophenyl butyrate (PNPB), was prepared by dissolving $20.9 \mathrm{mg}$ in $2 \mathrm{~mL}$ of acetonitrile. For each working test tube, $0.1 \mathrm{~mL}$ of porcine pancreatic lipase $(1 \mathrm{mg} / \mathrm{mL})$ was mixed with $0.2 \mathrm{~mL}$ of each diluted solution series for each plant fraction. The resulting mixture was then brought to a total volume of $1 \mathrm{~mL}$, by adding Tri- $\mathrm{HCl}$ solution and incubated at $37^{\circ} \mathrm{C}$ for $15 \mathrm{~min}$. Following the incubation period, $0.1 \mathrm{~mL}$ of PNPB solution was added to each test tube. The mixture was incubated for $30 \mathrm{~min}$ at $37^{\circ} \mathrm{C}$. Pancreatic lipase activity was determined by measuring the hydrolysis of the PNPB compound into $p$-nitrophenolate ions at $410 \mathrm{~nm}$ using a UV spectrophotometer. The same procedure was repeated for Orlistat, which was used as a standard reference compound. The equation used in this analytical study is shown below:

$$
\% \text { Lipase inhibition }=\left(A_{B}-A_{E}\right) / A_{B} \times 100 \%
$$

$A_{B}$ is the recorded absorbance of the blank solution; $\mathrm{A}_{\mathrm{E}}$ is the recorded absorbance of the E. alata sample solution.

\section{a-Amylase inhibition assay}

Each extract fraction was dissolved in a few milliliters of $10 \%$ DMSO and then further dissolved in buffer $(0.02 \mathrm{M}$ of $\mathrm{Na}_{2} \mathrm{HPO}_{4} / \mathrm{NaH}_{2} \mathrm{PO}_{4}, 0.006 \mathrm{M} \mathrm{NaCl}$, at $\left.\mathrm{pH} 6.9\right)$ to give concentrations of $1000 \mu \mathrm{g} / \mathrm{mL}$, from which the following dilutions were prepared: $10,50,70,100,500 \mu \mathrm{g} / \mathrm{mL}$. The porcine pancreatic $\alpha$-amylase enzyme solution was freshly prepared at a concentration of 2 units $/ \mathrm{mL}$ in $10 \%$ DMSO.

For working solutions, a volume of $0.2 \mathrm{~mL}$ of enzyme solution was mixed with $0.2 \mathrm{~mL}$ of each $E$. alata fruit extract fraction and was incubated for $10 \mathrm{~min}$ at $30{ }^{\circ} \mathrm{C}$. After the incubation period, $0.2 \mathrm{~mL}$ of a freshly prepared 1\% starch aqueous solution was added to each working solution, followed by an incubation period of at least $3 \mathrm{~min}$. The reaction was stopped by the addition of $0.2 \mathrm{~mL}$ dinitrosalicylic acid (DNSA) yellow color reagent. Each working solution was then diluted with $5 \mathrm{~mL}$ of distilled water and then boiled for $10 \mathrm{~min}$ in a water bath at $90^{\circ} \mathrm{C}$. The mixture was cooled to room temperature, and the absorbance was taken at $540 \mathrm{~nm}$. The blank was prepared following the same steps above, but the plant fraction was replaced with $0.2 \mathrm{~mL}$ of the previously described buffer. Acarbose was used as the standard reference following the same steps used for plant extract fractions [24].

The $\alpha$-amylase inhibitory activity was calculated using the following equation:

$$
\% \text { of } \alpha-\text { amylase inhibition }=\left(A_{B}-A_{E}\right) / A_{B} \times 100 \%
$$




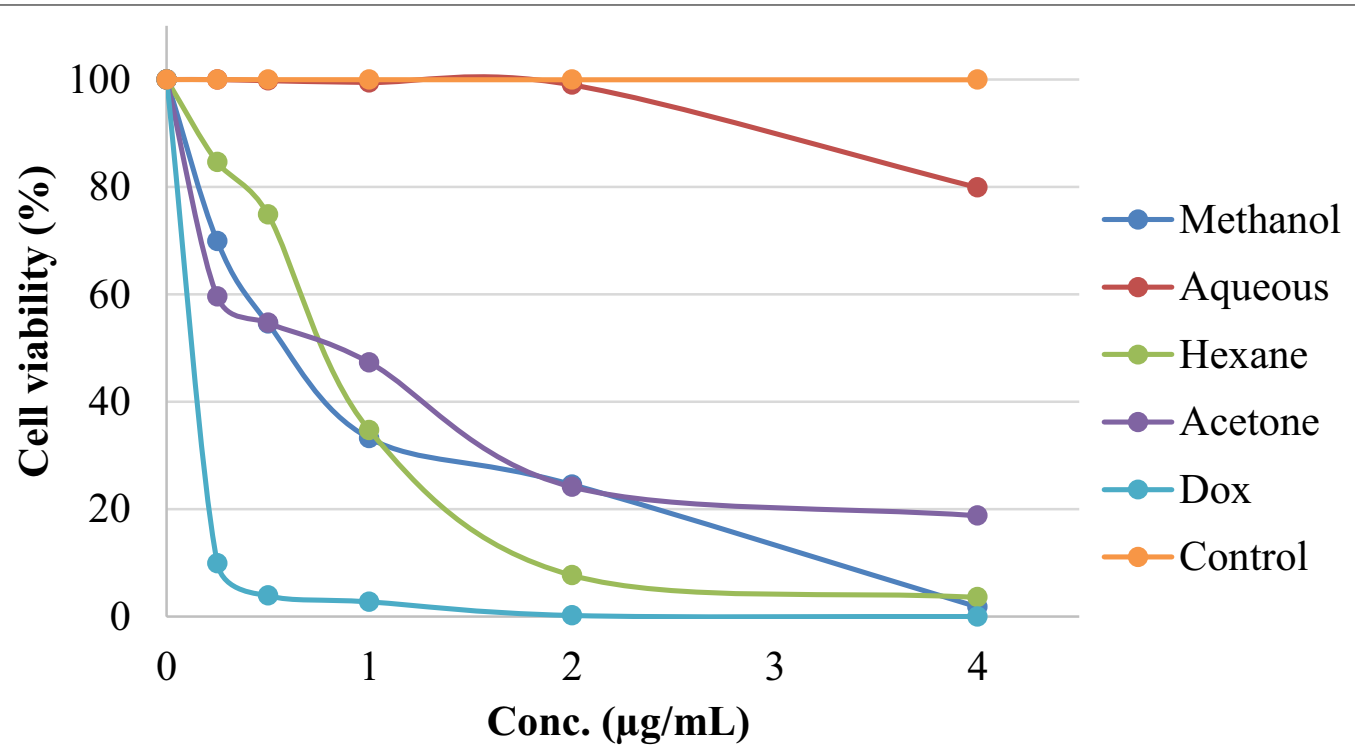

Fig. 6 Effects of the fractions in comparison with negative control (untreated) and positive control (Dox) on HeLa Cell Viability

$A_{B}$ : is the absorbance of blank; $A_{E}$ : is the absorbance of E. alata sample.

\section{a-Glucosidase inhibition assay}

The enzyme, alpha-glucosidase $(1 \mathrm{U} / \mathrm{mL})$, and $20 \mu \mathrm{L}$ of different concentrations of each extract fraction (100, $200,300,400$, and $500 \mathrm{mg} / \mathrm{mL}$ ) were added to a test tube. In each working test tube, a reaction mixture contained $0.1 \mathrm{~mL}$ of alpha-glucosidase solution was mixed with $0.2 \mathrm{~mL}$ from each extract dilution and $0.5 \mathrm{~mL}$ of phosphate buffer $(100 \mathrm{mM}, \mathrm{pH}=6.8)$. The samples were incubated at nearly $37^{\circ} \mathrm{C}$ for $15 \mathrm{~min}$. After this incubation period, $0.2 \mathrm{~mL}$ of $5 \mathrm{mM}$ PNPG (the substrate used for this experiment) was added to the reaction mixture, and the samples were again incubated at $37^{\circ} \mathrm{C}$ for $20 \mathrm{~min}$. The reaction was terminated by adding $0.1 \mathrm{M}$ sodium carbonate $\left(\mathrm{Na}_{2} \mathrm{CO}_{3}\right)$. The absorbance at the $405 \mathrm{~nm}$ wavelength was recorded for all samples. Acarbose was used as a positive control at the same concentrations as the plant extracts [25]. The results were expressed as percentage inhibition according to the following equation:

$$
\alpha \text {-Glucosidase inhibition }(\%)=\left(\mathrm{A}_{\mathrm{B}}-\mathrm{A}_{\mathrm{E}} / \mathrm{A}_{\mathrm{B}}\right) \times 100 \%
$$

$A_{B}$ is the absorbance without enzyme inhibitor; $A_{E}$ is the absorbance in the presence of $E$. alata sample.

\section{MTS assay}

HeLa cervical adenocarcinoma cells were cultured in RPMI-1640 media supplemented with 10\% fetal bovine serum, 1\% Penicillin/Streptomycin antibiotics, and
$1 \%$ L-glutamine. The cells were grown in a humidified atmosphere with $5 \% \mathrm{CO}_{2}$ at $37^{\circ} \mathrm{C}$. The cells were seeded at $2.6 \times 10^{4}$ cells/well in a 96-well plate. After $48 \mathrm{~h}$, the cells were incubated with various concentrations of the tested compounds for $24 \mathrm{~h}$. Cell viability was assessed by Cell Tilter $96^{\circledR}$ Aqueous One Solution Cell Proliferation (MTS) Assay according to the manufacturer's instructions (Promega Corporation, Madison, WI, USA). Briefly, at the end of the treatment, $20 \mu \mathrm{L}$ of MTS solution per $100 \mu \mathrm{L}$ of media was added to each well and incubated at $37^{\circ} \mathrm{C}$ for $2 \mathrm{~h}$. The absorbance was measured at $490 \mathrm{~nm}$ [26].

\section{Statistical analysis}

All of the obtained results of the four studied E. alata fruit fractions were expressed as mean $\pm S D$ standard deviation and the results were considered significant when the $p$-value was $<0.05$. The percentage contents of E. alata plant and the bioactivity of its extracted samples were subjected to principal component analysis (PCA) and partial least-squares discriminant analysis (PLS-DA) with the aid of SIMCA software 14.1. Score scatter plot and Loading scatter plot were generated. The $\mathrm{X}$-axis and $\mathrm{Y}$-axis represent score vectors summarizing all the variables entering the analysis.

\section{Results and discussion Phytochemical screening}

After performing the previously mentioned phytochemical laboratory tests, it was observed that the different $E$. 


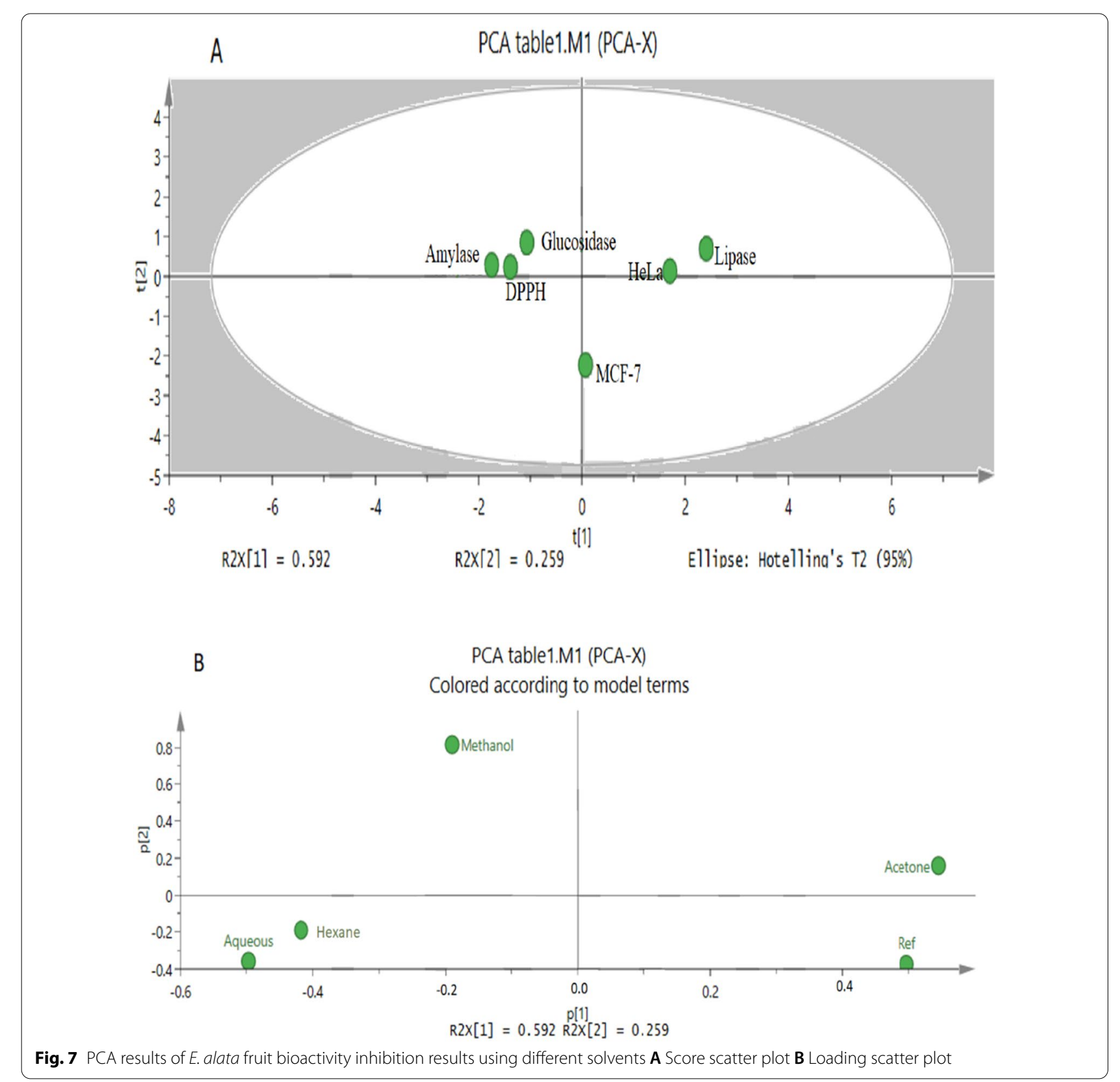

alata fruit extract fractions contained a variety of active phytochemical ingredients, which were summarized in Table 1. It was observed that the alternative fractionation process, adding different solvents in this extraction method, was effective in separating the active phytoconstituents from each other. Proteins, saponin, reducing sugars, and starches were collected intensively in the aqueous fraction, while alkaloids appeared in all extract fractions. Flavonoids, which are always resembled antioxidant activity, appeared in all extract fractions, and they were found in high quantity in the methanol layer.
Phenols and tannins were observed in all fractions but seemed to be concentrated in the methanol layer. Positive results for volatile oil were found in the methanol fraction, confirming that the presence of one of the alcoholtype volatile oils.

As shown in Table 2, the percent yield results recorded after calculations of each extract fraction revealed that the highest yield was observed in the methanolic fraction, which was $29 \%$, followed by the acetone and aqueous fractions, which were $15.6 \%$ and $15.08 \%$, respectively. 


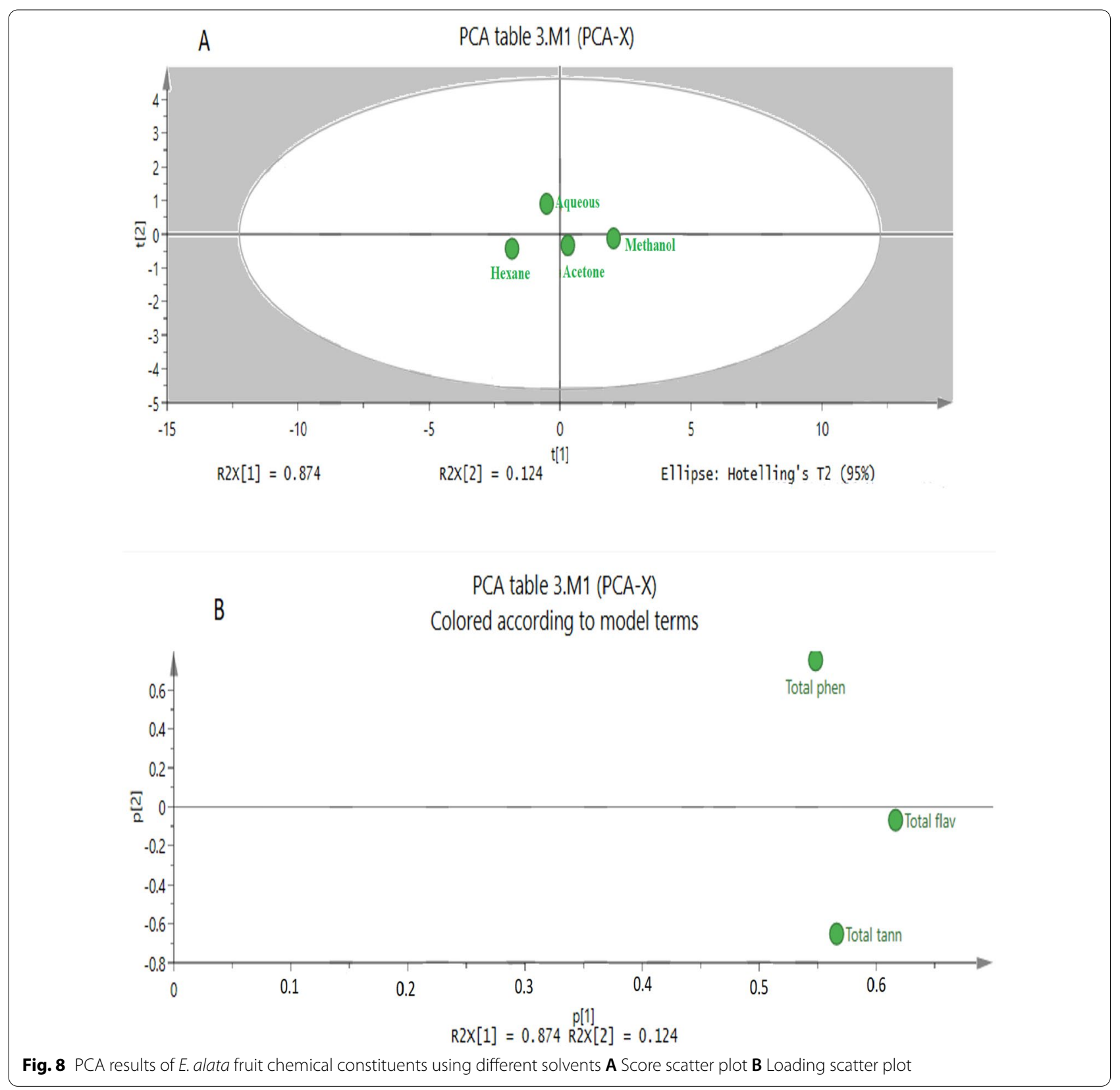

\section{Quantitative analysis of TPC, TFC, and TTC}

For the evaluation of TPC, TFC, and TTC, the absorption (Abs) values of several concentrations of the Gallic acid, Rutin, and Catechin standards (STDs) are shown in Table 3, and regarding these points, three equations were obtained for each STD versus its concentrations to calculate the total phenol, flavonoid, and tannin contents of the hexane, acetone, methanol, and aqueous E. alata fruits fractions are presented in Table 4.

\section{Antioxidant activity}

The results of assessing the free radical scavenging activity of four fractions from E. alata fruits, using Trolox as a reference antioxidant agent, were expressed as percentage DPPH inhibition (Fig. 2 and Table 5). Therefore, $E$. alata fruits could be considered an herbal source for antioxidants, especially for the methanol fraction, which had an $\mathrm{IC}_{50}$ value of $1.70 \pm 0.25 \mu \mathrm{g} / \mathrm{mL}$. Similar results were also obtained for the acetone fraction, which showed an 
$\mathrm{IC}_{50}$ value of $5.00 \pm 0.51 \mu \mathrm{g} / \mathrm{mL}$. The results were compared to Trolox, a potent antioxidant compound, with an $\mathrm{IC}_{50}$ equal to $2.04 \pm 0.74 \mu \mathrm{g} / \mathrm{mL}$. By contrast, the aqueous fraction only showed moderate antioxidant activity, with a higher $\mathrm{IC}_{50}$ value of $15.25 \pm 0.30 \mu \mathrm{g} / \mathrm{mL}$.

These observations confirmed the results of the quantitative analyses of phenols, flavonoids, and tannins, which showed a high flavonoid and phenol content in the methanol extract fraction, which was equal to $98.95 \pm 2.3 \mathrm{mg}$ of RUE/g of dry extract and $33.22 \pm 1.56 \mathrm{mg}$ of GAE/g of dry extract, respectively. Tannins also showed the highest content in the methanol fraction with a value equal to $17.5 \pm 0.70 \mathrm{mg}$ of $\mathrm{CAE} / \mathrm{g}$ of dry extract. In general, the phenolic content of all the extracts was considerably high, which could be a major contributor to the strong antioxidant effect of $E$. alata fruit extracts. Therefore, the high phenolic content in fruit extracts will explain these results of high antioxidant activity [27].

\section{Lipase inhibition activity}

In this assay, the anti-obesity activity of fractions from $E$. alata fruits extracts was compared to that of orlistat, a positive control (Fig. 3 and Table 5). E. alata fruits were an excellent alternative natural source of lipase inhibitory agents. The methanol fraction showed an $\mathrm{IC}_{50}$ value of $66.48 \pm 0.50 \mu \mathrm{g} / \mathrm{mL}$, which was the most potent fraction in comparison with the reference compound orlistat $(12.3 \pm 0.33 \mu \mathrm{g} / \mathrm{mL})$. However, acetone fraction showed a similar inhibition profile as methanol, while hexane and aqueous fractions were showed weak inhibitory activity with $\mathrm{IC}_{50}$ values $77.56,277.25$, and $274.407 \mu \mathrm{g} / \mathrm{mL}$ respectively. These observations confirmed the results of the quantitative analyses of phenols, flavonoids, and tannins that showed a high content of flavonoids and phenols in the methanol extract fraction mentioned before.

\section{a-Amylase inhibition activity}

In this assay, the $\alpha$-amylase inhibitory activity of fractions from E. alata fruits extract was compared to the positive control Acarbose (Fig. 4). The methanol fraction was the most potent inhibitor of $\alpha$-amylase, with an $\mathrm{IC}_{50}$ of $9.43 \pm 0.6 \mu \mathrm{g} / \mathrm{mL}$, compared to $28.84 \pm 1.22 \mu \mathrm{g} / \mathrm{mL}$ for acarbose, the reference compound, and the aqueous fraction has similar activity with $\mathrm{IC}_{50} 16.37 \pm 0.58 \mu \mathrm{g} / \mathrm{mL}$. in contrast, the other fractions have weaker activities against this enzyme (Table 5). The results obtained in this research, especially for the methanol fraction which possessed the highest phenolic content, provide additional evidence that is in line with previous studies that natural polyphenols can inhibit the activity of carbohydrate hydrolyzing enzymes like $\alpha$-amylase and $\alpha$-glucosidase [28].

\section{a-Glucosidase inhibition activity}

Results of $\alpha$-glucosidase were compared with those of acarbose, positive control, and the $\mathrm{IC}_{50}$ values were calculated for the four fractions (Table 5 and Fig. 5). The methanol fraction exerted the greatest inhibitory action on $\alpha$-glucosidase with an $\mathrm{IC}_{50}$ of $46.16 \pm 0.63 \mu \mathrm{g} /$ $\mathrm{mL}$, compared with that of acarbose, the reference control, at $37.15 \pm 0.33 \mu \mathrm{g} / \mathrm{mL}$. In contrast, the other fractions showed moderate to negligible inhibition of $\alpha$-glucosidase. The results obtained in this study confirmed previously observed results that revealed the activity of phenolic compounds like $p$-hydroxybenzoic acid, as well as trans-p-coumaric acid and epicatechin gallate, and flavonoids, like quercetin that are present in lentil extracts, to be effective inhibitors of some digestive enzymes lipase and $\alpha$-glycosidase contributing to controlling glucose levels in the blood, as well as the management of obesity [29].

\section{Anti-proliferative activity}

The results of treatment of HeLa cancer cells with five different concentrations in $\mathrm{mg} / \mathrm{mL}$ for different fractions showed that methanol, acetone, and hexane fractions have cytotoxic activities with $\mathrm{IC}_{50}$ range $604-764 \mu \mathrm{g} / \mathrm{mL}$ while the aqueous fraction has no activity. The cell viability graph (Fig. 6) showed the activity of these fractions in comparison with negative control and positive control (Doxorubicin). In previous studies on cytotoxicity of the hydroalcoholic extract of the aerial part of E. alata, the results showed that the extract contained polyphenolic phyto-compounds and had anti-proliferative, pro-apoptotic, and cytotoxic potential against the MCF-7 human breast cancer cell line [30]. But in our study, the anticancer activity can be considered as very weak in comparison with anticancer drugs such as the used positive control Doxorubicin.

\section{Principal component analysis (PCA)}

Principal component analysis (PCA) is the statistical tool which was used to discuss the variations between different samples and to find more data on the variables which influence the sample similarities and differences [31]. The score plot (Fig. 7A) shows that the product has similarity of inhibition activities for amylase, DPPH and glucosidase. Theses bioactivities were opposite in terms of potency for lipase and cytotoxicity of HeLa cells. However, the cytotoxicity against MCF-7 is similar regardless of the extracting solvent. Loading scatter plot (Fig. 7B) shows that solvent methanol has the largest absolute loading values. The chemical constituents of the plant were also analyzed using the SIMCA program. The generated Score scatter plot Fig. 8A demonstrate that Hexane solvent has an extraction capability opposite to 
that of methanol while the aqueous and acetone solvent were we not distinguishable. The loading scatter plot Fig. $8 \mathrm{~B}$ shows that total phenol has the largest absolute loading values. Regarding the data obtained from PCA, there is a clear relationship between the activities of methanol fraction as the most active fraction towered various biological targets and the highest percentage of TFC, TPC, TTC in this fraction.

\section{Conclusion}

The E. alata fruit extracts analysis showed that it contains a mixture of different phytochemicals such as protein, amino acid, reducing sugars, and saponin, in addition to phenols, tannins, and flavonoids which seems to be in high quantity in particular in the methanol extract. The methanol extract has potent antioxidant, $\alpha$-amylase, and $\alpha$-glucosidase inhibition, and moderate lipase inhibitory activity. Therefore, the methanol extract fraction of E. alata provides a scientific rationale for the use in the pharmaceutical industry as a low-cost nutrient useful in reducing chronic pathologies such as diabetes mellitus, obesity, and oxidative stress. The methanol extract fraction was shown to be a potent inhibitor of starch digestive enzymes due to the high content of phenolic compounds and flavonoids, and it was found to be effective in free radical scavenging and lipase enzyme inhibition. In addition, the methanol extract derived from $E$. alata fruits induced cytotoxicity at a higher concentration by approximately $94 \%$, and therefore, it may represent a good choice for some of the health beneficial herbal supplements and natural medications used in cancer management and can be further subjected for the isolation of the therapeutically active compounds.

\begin{abstract}
Abbreviations
DPPH: 2, 2-Diphenyl-1-picrylhydrazyl; $I C_{50}$ : Half maximal inhibitory concentration; E. alata: Ephedra alata; PNPG: $p$-Nitrophenyl glucopyranoside; PNPG: p-Nitrophenyl glucopyranoside; Trolox: ((S)-(-)-6 hydroxy-2,5,7,8-tetramethychroman-2-carboxylic acid); $A_{B}$ : Absorbance of the blank solution; $A_{E}$ : Absorbance of the $E$. alata sample solution; PNPB: $p$-Nitrophenyl butyrate; CAE: Catechin equivalent; GAE: Gallic acid equivalent; RUE: Rutin equivalent; WHO: World Health Organization; DM: Diabetic mellitus; DNSA: 3,5-Dinitrosalicylic acid; TPC: Total phenols content; TFC: Total flavonoid content; TTC: Total tannin content; CA: Principal component analysis.
\end{abstract}

\section{Acknowledgements}

The authors would like to acknowledge the Faculty of Graduate Studies at An-Najah National University.

\section{Authors' contributions}

$\mathrm{NJ}$ and $\mathrm{HD}$ conceived and designed the current study. MH and MNA analyzed the data obtained. This paper was written by $\mathrm{NJ}, \mathrm{HD}$, and $\mathrm{MH}$, and drafted by all authors. All authors read and approved the final manuscript.

\section{Funding}

This research was not funded.
Availability of data and materials

The datasets used and/or analyzed during the current study available from the corresponding author on reasonable request.

\section{Declarations}

Ethics approval and consent to participate

Not applicable.

\section{Consent for publication}

Not applicable.

\section{Competing interests}

The authors declare that they have no competing interests.

Received: 4 March 2021 Accepted: 14 June 2021

Published online: 26 June 2021

\section{References}

1. Bensky D, Clavey S, Stõger E (2004) Materia medica, 3rd edn. Eastlandpress, Seattle

2. Alqarawi A, Hashem A, Abd-Allah E, Alshahrani T, Huqail A (2014) Effect of salinity on moisture content, pigment system, and lipid composition in Ephedra alata Decne. Acta Biol Hung 65(1):61-71

3. Caveney S, Charlet DA, Freitag H, Maier-Stolte M, Starratt AN (2001) New observations on the secondary chemistry of world Ephedra (Ephedraceae). Am J Bot 88(7):1199-1208

4. Nawwar M, Barakat H, Buddrust J, Linscheidt M (1985) Alkaloidal, lignan and phenolic constituents of Ephedra alata. Phytochemistry 24(4):878-879

5. Al-Qarawi A, Abd Allah E, Hashem A (2012) Effect of Ephedra alata on nucleic acids and nitrogen metabolism of seedborne Aspergillus flavus. Pak J Bot 44(1):425-428

6. Freitag H, Maier-Stolte M (2003) The genus Ephedra in NE tropical Africa. Kew Bull 58:415-426

7. Abourashed EA, El-Alfy AT, Khan IA, Walker L (2003) Ephedra in perspective-a current review. Phytother Res 17(7):703-712

8. Ghanem S, El-Magly UI (2008) Antimicrobial activity and tentative identification of active compounds from the medicinal Ephedra alata male plant. J Taibah Univ Med Sci 3(1):7-15

9. Al-Rimawi F, Abu-Lafi S, Abbadi J, Alamarneh AA, Sawahreh RA, Odeh I (2017) Analysis of phenolic and flavonoids of wild Ephedra alata plant extracts by LC/PDA and LC/MS and their antioxidant activity. Afr J Tradit Complement Altern Med 14(2):130-141

10. Jadhav S, Nimbalkar S, Kulkarni A, Madhavi D (1995) Lipid oxidation in biological and food systems. Food antioxidants. CRC Press, USA, pp 19-78

11. Bustanji Y, Issa A, Mohammad M, Hudaib M, Tawah K, Alkhatib H et al (2010) Inhibition of hormone sensitive lipase and pancreatic lipase by Rosmarinus officinalis extract and selected phenolic constituents. J Med Plant Res 4(21):2235-2242

12. Zheng C-D, Duan Y-Q, Gao J-M, Ruan Z-G (2010) Screening for antilipase properties of 37 traditional Chinese medicinal herbs. Chin Med J 73(6):319-324

13. Mosleh R, Hawash M, Jarrar Y (2020) The relationships among the organizational factors of a tertiary healthcare center for type 2 diabetic patients in palestine. Endocr Metab Immune Disord Drug Targets 20:65-72

14. Tiwari A, Swapna M, Ayesha S, Zehra A, Agawane S, Madhusudana K (2011) Identification of proglycemic and antihyperglycemic activity in antioxidant rich fraction of some common food grains. Int Food Res J 18(3):915-923

15. Wadkar K, Magdum C, Patil S, Naikwade N (2008) Antidiabetic potential and Indian medicinal plants. J Herb Med Tox 2(1):45-50

16. La Regina G, Bai R, Rensen W, Coluccia A, Piscitelli F, Gatti V et al (2011) Design and synthesis of 2-heterocyclyl-3-arylthio-1h-indoles as potent tubulin polymerization and cell growth inhibitors with improved metabolic stability. J Med Chem 54(24):8394-8406

17. Jacobo-Herrera NJ, Jacobo-Herrera FE, Zentella-Dehesa A, Andrade-Cetto A, Heinrich M, Pérez-Plasencia C (2016) Medicinal plants used in Mexican 
traditional medicine for the treatment of colorectal cancer. J Ethnopharmacol 179:391-402

18. Michel C, El-sherei M, Islam W, Sleem A, Ahmed S (2013) Bioactivityguided fractionation of the stem bark extract of Pterocarpus dalbergioides Roxb. ex Dc growing in Egypt. Bull Fac Pharm Cairo Univ. 51 (1):1-5

19. Cheung L, Cheung PC, Ooi VE (2003) Antioxidant activity and total phenolics of edible mushroom extracts. Food Chem 81(2):249-255

20. Chang C-C, Yang M-H, Wen H-M, Chern J-C (2002) Estimation of total flavonoid content in propolis by two complementary colorimetric methods. J Food Drug Anal 10(3):178-182

21. Sun B, Ricardo-da-Silva JM, Spranger I (1998) Critical factors of vanillin assay for catechins and proanthocyanidins. J Agric Food Chem 46(10):4267-4274

22. Alali FQ, Tawaha K, El-Elimat T, Syouf M, El-Fayad M, Abulaila K et al (2007) Antioxidant activity and total phenolic content of aqueous and methanolic extracts of Jordanian plants: an ICBG project. Nat Prod Res 21(12):1121-1131

23. Drent M, Larsson I, William-Olsson T, Quaade F, Czubayko F, Strobel W et al (1995) Orlistat (Ro 18-0647), a lipase inhibitor, in the treatment of human obesity: a multiple dose study. Int J Obes Relat Metab Disord 19(4):221-226

24. Sudha P, Zinjarde SS, Bhargava SY, Kumar AR (2011) Potent a-amylase inhibitory activity of Indian Ayurvedic medicinal plants. BMC Complement Altern Med 11(1):5

25. Ademiluyi AO, Oboh G (2013) Soybean phenolic-rich extracts inhibit key-enzymes linked to type 2 diabetes (a-amylase and a-glucosidase) and hypertension (angiotensin I converting enzyme) in vitro. Exp Toxicol Pathol 65(3):305-309
26. Mosmann T (1983) Rapid colorimetric assay for cellular growth and survival: application to proliferation and cytotoxicity assays. J Immunol Methods 65(1-2):55-63

27. Afolayan A, Jimoh F, Sofidiya M, Koduru S, Lewu F (2007) Medicinal Potential of the Root of Arctotis arctotoides. Pharm Biol 45(6):486-493

28. Tundis R, Loizzo M, Menichini F (2010) Natural products as a-amylase and a-glucosidase inhibitors and their hypoglycaemic potential in the treatment of diabetes: an update. Mini Rev Med Chem 10(4):315-331

29. Zhang B, Deng Z, Ramdath DD, Tang Y, Chen PX, Liu R et al (2015) Phenolic profiles of 20 Canadian lentil cultivars and their contribution to antioxidant activity and inhibitory effects on a-glucosidase and pancreatic lipase. Food Chem 172:862-872

30. Corina D, Delia M, Ersilia A, Claudia F, Istvan O, Andrea B et al (2019) Phytochemical characterization and evaluation of the antimicrobial, antiproliferative and pro-apoptotic potential of Ephedra alata Decne. Hydroalcoholic extract against the MCF-7 breast cancer cell line. Molecules 24(1):13. https://doi.org/10.3390/molecules24010013

31. Šamec D, Maretić M, Lugarić I, Mešić A, Salopek-Sondi B, Duralija B (2016) Assessment of the differences in the physical, chemical and phytochemical properties of four strawberry cultivars using principal component analysis. Food Chem 194:828-834

\section{Publisher's Note}

Springer Nature remains neutral with regard to jurisdictional claims in published maps and institutional affiliations.
Ready to submit your research? Choose BMC and benefit from:

- fast, convenient online submission

- thorough peer review by experienced researchers in your field

- rapid publication on acceptance

- support for research data, including large and complex data types

- gold Open Access which fosters wider collaboration and increased citations

- maximum visibility for your research: over $100 \mathrm{M}$ website views per year

At BMC, research is always in progress.

Learn more biomedcentral.com/submissions 